GLOBAL JOURNAL OF AGRICULTURAL SCIENCES VOL. 16, 2017: 67-73

COPYRIGHT@ BACHUDO SCIENCE CO. LTD PRINTED IN NIGERIA ISSN 1596-2903

\title{
ANALYSIS OF COST EFFICIENCY OF RAINFED MAIZE PRODUCTION IN YOLA NORTH AND YOLA SOUTH LOCAL GOVERNMENT AREAS OF ADAMAWA STATE, NIGERIA
}

\author{
M. ABDUL, A. K. TASHIKALMA, D. C. MAURICE AND F. M. SHITTU
}

(Received 2 June 2016; Revision Accepted 12 July 2016)

\begin{abstract}
This study analyzed the allocative (cost) efficiency of rainfed maize production in Yola North and Yola South Local Government Areas of Adamawa State, Nigeria. Purposive and simple random sampling techniques were used to select 128 respondents. The data collected were analyzed using descriptive statistics and stochastic frontier cost function model. Results revealed that the respondents had a mean age of 39 years and have large household sizes. The sampled farmers are experienced and cultivated an average of about two hectares of land. The respondents had also acquired one form of formal education or the other with primary school as the least. The results of the maximum likelihood estimate parameters of the stochastic frontier cost function revealed that cost of land and cost of seeds, cost of hired labour and cost of agrochemicals were significant at different level of probabilities. The allocative efficiency indices revealed that allocative efficiency of the sampled farmers ranged from 0.44 to 0.98 with a mean of 0.68 , implying that an average farmer in the study area has the scope for increasing cost efficiency by $32 \%$ given the existing technology. The study recommends provision of adequate farm inputs and essential services at low cost to rainfed maize farmers.
\end{abstract}

KEYWORDS: Cost efficiency, rainfed, maize production, Yola, Adamawa, Nigeria

\section{INTRODUCTION}

Agriculture sector has been playing a tremendous role in the life of people especially in terms of supply of food, provision of employment and source of raw materials for agro-based industry in Nigeria. Despite the important of agricultural sector in the country, the level of food insecurity has continued to rise steadily in Nigeria since 1980's. According to Uche (2012), food insecurity situation is still an undeniable socio-economic reality in the country. An attempt to maximize profit or output in production requires efficient use of farm resources (Umoh, 2006). This is because the scope of agricultural production can be expanded and sustained by farmers through efficient use of resources (Ali, 1996; Udoh 2005). Maize is one of the major food crops that is been process into varieties of food item like maize flour, "masa", pop corn excetra which form staple food for most Nigerian. According to Iken and Amusa (2004), research on methods of cultivating maize to a large extent is secondary since designing of efficient farming system was given a priority. Umoh (2006) also concluded that efficiency has remained an important subject of empirical investigation particularly in developing economies where majority of farmers are resource - poor. It has been observed that maize has not been produced to meet the demand of the people within and around Yola metropolis in Adamawa State, Nigeria. For this reason, the study was conducted to analyze cost efficiency of rainfed maize farming in Yola North and Yola South Local Government Area of Adamawa State. The specific objectives are to: (i) describe the socio-economic characteristics of the respondents and (ii) estimate the allocative efficiency of the maize farming in the study area.

\section{Conceptual and Theoretical Framework}

Efficiency remains an important aspect that needs to be considered in agriculture in order to increase production and distribution of resources optimally so as to meet the food demand of the populace. Attention in agriculture has shifted long ago from mere production to efficiency in production by giving more priority to the optimum production plan in order to maximize yield or minimize cost of production or maximize profit or combination of these as they reflect the key objectives of any business firm. It is imperative that measures should be tailored at the search for minimum of each production resource that is needed for maximizing the utilization of all other resources at their least possible costs to attain the optimum cost efficiency of a firm.

M. Abdul, Department of Agricultural Economics and Extension, Moddibo Adama University of Technology, P.M.B 2076, Yola, Nigeria.

A. K. Tashikalma, Department of Agricultural Economics and Extension, Moddibo Adama University of Technology, P.M.B 2076, Yola, Nigeria.

D. C. Maurice, Department of Agricultural Economics and Extension, Moddibo Adama University of Technology, P.M.B 2076, Yola, Nigeria.

F. M. Shittu, National Institute for Cultural Orientation, P.O. Box 1132, Ribadu Square, Yola, Nigeria. 
The efficient input distribution mix will help a firm to allocate input resources without being underutilized or over-utilized. Allocative efficiency is a measure of the degree of success in achieving the best combination of different inputs in producing a specific level of outputs considering the relative prices if inputs (Olayide and Heady 1982). It is against this background that Onuk et al. (2010) in their study of economic analysis of maize production in Mangu Local Government Area of Plateau State, Nigeria said to achieve optimum allocative efficiency of variable inputs, policies and programmes should be directed to maize farmers in order to increase their level of use of farm land, labour, capital and other miscellaneous inputs.

Paudel and Matsouka (2009) analyzed the cost efficiency of maize production in the Chitwan district, Nepal with a view to predicting economic efficiencies using stochastic frontier cost function. The maximum likelihood estimates parameters revealed that estimated coefficient of cost of tractor, animal power, labour, fertilizer, manure, seed, and maize output gave positive coefficients and were statistically significant at $5 \%$ level. The quantitative estimates obtained from the cost function revealed that an average maize farm from the study incurred about $63 \%$ costs above the cost frontier, an indication of inefficiency.

Kareem et al. (2009) made a comparative analysis between concrete ponds and earthen ponds in order to determine the economic efficiency of fish farming in Ogun State, Nigeria. The result of the estimated allocative efficiency of fish farming with respect to concrete ponds shows that cost of labour was significant at $5 \%$ level while cost of lime with respect to earthen ponds was shown to be a significant variable at $1 \%$ in the allocative efficiency model.

Giroh (2012) conduct a study on the efficiency of latex production and labour productivity in rubber plantation in Edo and Delta State, Nigeria. The estimates of the parameters of the stochastic cost frontier analysis showed that safety kits, cost of labour and output were significantly related to the cost of production with mean allocative efficiency of 0.77 while minimum and maximum allocative indices were 0.27 and 0.99 respectively. The study further revealed that age, extension contact and farm distance enhance the allocative efficiency of rubber farmers in the study area.

Zalkuwi et al. (2014) analysed the determinants of cost efficiency in cowpea production in Adamawa State, Nigeria using stochastic cost frontier. The mean allocative efficiency was estimated at 0.66 , indicating that farmers operate at $34 \%$ below the cost frontier. The inefficiency models revealed that socio economic variables, namely: family size, farming experience, gender and extension contact has significantly reduce cost inefficiency among the farmers.
Maurice et al. (2015) employed stochastic frontier cost function to analyze and determine the cost efficiency in food crop production among small-scale farmers in Adamawa State, Nigeria. The result of the maximum likelihood estimates of the stochastic frontier cost function revealed that the explanatory variables: extension contact, crop diversification and credit availability were significantly and positively related to the cost efficiency in the study area. The result also showed that cost efficiency index ranged from 0.18 to 0.98 with mean of 0.84 implying that an average farmer in the study area has the scope of increasing cost efficiency by $14 \%$ given the existing technology. Hence, the farmers in the study area operated below the cost efficiency frontier.

\section{METHODOLOGY}

\section{The Study Area}

The study was carried out in Yola North and Yola South Local Government Area of Adamawa State, North-East geopolitical zone of Nigeria. The state has Yola as its state capital. Yola North Local Government area lies between latitude $9^{\circ} 14^{\prime \prime} \mathrm{N}$ and longitude $12^{\circ}$ 38 " $\mathrm{E}$, while Yola South lies between latitude $9^{0} 14^{\prime \prime} \mathrm{N}$ and longitude $12^{\circ} 28$ "E. Both the Local Government Areas have tropical climate marked by distinct rainy and dry seasons. The area has a mean temperature of $34.56^{\circ} \mathrm{C}$ with maximum temperature of $40^{\circ} \mathrm{C}$, while the minimum temperature can be as low as $18^{\circ} \mathrm{C}$. The mean annual rainfall is less than $1,000 \mathrm{~mm}$ (Adamawa State Government Diary, 2013). Yola North has a land mass of about $1,913 \mathrm{~km}^{2}$ while Yola South has a land mass of about $1,293 \mathrm{~km}^{2}$, both situated in the Sudan savannah vegetation zone of the country. The projected population of Yola North and Yola South Local Government from 2006 population census based on $2.9 \%$ annual growth rate were put at 230, 414 and 207, 185 respectively (Adamawa State Primary Health Care Development Agency, 2014). The study area share common boundaries with Fufore Local Government Area to the South-east, Mayo-Belwa Local Government Area to the south-west, Demsa Local Government Area to the North- west and Girei Local Government Area to the North-east. The area has a number of ethnic groups speaking different languages. Fulfulde and Hausa are widely spoken in the area. Agriculture is the dominant occupation of the major inhabitant of the area. Some of the crops produced in the area include Groundnuts, Cotton, Maize, Cassava, Yam, Guinea corn, Millet, Beans, Sweet potato and Rice. Other occupations include Cattle rearing, fruit production and trading (Adamawa State Government Diary, 2013). 
Sampling Procedure and Method of Data collection

Data for the study were obtained from primary source which were collected through the use of structured questionnaires as well as interview schedule, which were administered to rainfed maize farmers in the study area. Purposive and simple random sampling techniques were employed in selecting the sampled farmers. Ten (10) wards from the two Local Government Areas (Yola North and Yola South) were purposively selected where maize farming is predominant while a random selection of 160 rainfed maize farmers proportionate to size were sampled from the existing sampling frame as shown in Appendix 1.

$S=p / P \cdot Q / 1$

Where $S=$ Sample size; $p=$ Population of each location; $P=$ Total population; $Q=$ Total number of respondents. However, 128 questionnaires were returned with useful information and were used for the study.

\section{Method of Data Analysis}

Descriptive statistics (include percentages, arithmetic mean, and frequency tables) was used to achieve objectives i while stochastic frontier model was used to achieve objective ii. Stochastic frontier cost function was used for assessing allocative efficiency in maize production in the study area.

\section{Stochastic frontier cost function}

The stochastic frontier cost function as adopted by Ogundari and Ojo (2007) can be written in general form as:

$\mathrm{C}^{*}{ }_{\mathrm{x}}=f\left(\mathrm{P}_{\mathrm{x},}, \mathrm{Y}^{*}{ }_{\mathrm{x}} ; \beta\right)+(\mathrm{V}+\mathrm{U})$

Where:

$C^{*}{ }_{x}=$ Frontier cost of production of the $i^{\text {th }}$ firm; $P_{x}=$ Cost of input prices;

$Y^{*}{ }_{x}=$ Output of the $i^{\text {th }}$ firm; $\beta=$ Vector of the parameter to be estimated;

$V=$ Random disturbance cost due to factors outside the control of the farmer; and

$\mathrm{U}=$ One sided disturbance term representing the cost inefficiency.

The cost efficiency of an individual firm is defined as the ratio of observed cost $\left(C^{b}\right)$ to the corresponding minimum cost $\left(\mathrm{C}^{\mathrm{min}}\right)$ under a given technology.

So that: $\mathrm{CE}=\left(\mathrm{C}^{\mathrm{b}}\right) /\left(\mathrm{C}^{\mathrm{min}}\right)=\frac{f\left(\mathrm{P}_{\mathrm{x}}, \mathrm{Y}^{*}{ }_{\mathrm{x}} ; \beta\right)+(\mathrm{V}+\mathrm{U})}{f\left(\mathrm{P}_{\mathrm{x}}, \mathrm{Y}^{*}{ }_{\mathrm{x}} ; \beta\right)+(\mathrm{V})}=\exp (\mathrm{U})$

Where: CE = Cost efficiency;

$\mathrm{C}^{\mathrm{b}}=$ the observed cost and it represents the actual total cost of production;

$\mathrm{C}^{\mathrm{min}}=$ the minimum cost and it represents the frontier total cost of production, otherwise known as the least cost of production. Cost efficiency takes the value of 1 indentifying cost efficient firm (Obidi, 2009).

The cost frontier model for this study is written explicitly as:

In $C_{i}=\beta_{0}+\beta_{1} \ln P_{1}+\beta_{2} \ln P_{2}+\beta_{3} \ln P_{3}+\beta_{4} \ln P_{4}+\beta_{5} \ln P_{5}+\beta_{6} \ln P_{6}+V i+U i$

$C_{i}=$ Total cost of production (input price $x$ input of the $i^{\text {th }}$ farm in kilogramme);

$P_{1}=$ Rent on land $(A) ; P_{2}=$ Cost of seed used $(A) ; P_{3}=$ Cost of fertilizer used $(A)$;

$\mathrm{P}_{4}=$ Cost of family labour used $(\mathbb{A}) ; \mathrm{P}_{5}=$ Cost of hired labour used $(\mathbb{A})$; and

$P_{6}=$ Cost of agrochemical used $(\mathrm{N})$; and $L n=$ Natural logarithm.

The allocative efficiency measure was computed as the inverse of the cost efficiency, and ranges from zero to one.

\section{RESULTS AND DISCUSSIONS}

The summary statistics of the socio-economic variables of the respondents is presented in Table 1. The table showed that the mean age of the sampled farmers is 39 years with a minimum and maximum age of 21 and 81 respectively an indication that they are economically active to participate in farming activities. Respondents have large household size with mean household size of 9 people, experienced and are small scale cultivators using a mean farm size of 2.06 hectares of land. They also had one form of education or the other with primary school as the least. Thus, farmers are expected to be highly productive based on their educational background and experience. This conforms to the study of Ogundele (2003) who reported that education plays a significant role in skill acquisition and knowledge transfer. 
Table 1: Socio-economic characteristic of the respondents

\begin{tabular}{lcll}
\hline Variables & Mean & Minimum & Maximum \\
\hline Age & 39.0 & 21 & 80 \\
Household size & 8.9 & 2 & 20 \\
Farming experience & 21.0 & 3 & 51 \\
Farm size & 2.6 & 0.5 & 6 \\
Education & 2.3 & 1 & 4 \\
\hline
\end{tabular}

Source: field survey, 2014

\section{Maximum Likelihood Estimate of the Stochastic Frontier cost function}

The maximum likelihood estimates of the parameters of the stochastic cost frontier model used in estimating allocative efficiency was presented in table 2 . The estimated gamma $(\mathrm{Y})$ parameter $(0.8286)$ is highly significant at $1 \%$ level, indicating that $82.86 \%$ of the variation in the total cost of production among the sampled farmers was due to differences in their cost efficiencies thereby indicating the existence of allocative inefficiency. Sigma squared $\left(\sigma^{2}\right)$ on the other hand is 0.1283 and is statistically significant at $1 \%$ level indicating correctness of fit of the model as assumed for the composite error term.

Table 2 also revealed that all the parameter estimates except gender have the expected positive sign, where cost of land $\left(P_{1}\right)$, cost of seed $\left(P_{2}\right)$ were statistically significant at $1 \%$ level. The coefficient of cost of land $\left(\beta_{1}\right)$ was estimated to be 0.7283 meaning that an increase in the cost of rented land by $1 \%$ will cause the total cost of production to increase by $0.7283 \%$. Similarly, if the cost of seed increases by $1 \%$, the total cost of production will rise by $0.1586 \%$. This implies that these are the most critical factors affecting the total cost of production in the study area. Table 2 also revealed that hired labour $\left(P_{5}\right)$ and agrochemicals $\left(P_{6}\right)$ were statistically significant at $5 \%$ level, meaning that these factors are important determinants of total cost associated with maize crop production in the study area. That is, $1 \%$ increase in the cost of hired labour will increase total production cost to about $0.11 \%$. Also, $1 \%$ increase in the cost of agrochemicals will increase total production cost by $0.14 \%$.

The estimated coefficient of the explanatory variables in the inefficiency cost model shows that farming experience $\left(Z_{2}\right)$, education $\left(Z_{3}\right)$ and household size $\left(Z_{4}\right)$ were significant and also have the expected signs. Hence, they are the determinant of cost inefficiency in the study area. The coefficient of farming experience variable was estimated to be negative and statistically significant at $5 \%$ level, indicating that greater experience by the farmers tend to decrease allocative inefficiency in rainfed maize crop production. Consistency on job performance over years will help the farmers to make better decisions on cost minimization which helps in enhancing cost efficiency. This buttressed the findings of Ajibefun and Daramola (2003) who reported that more experienced farmers are expected to have higher efficiency than farmers with low farming experience given that farming business involved annual routine activity.

The statistical significance of education as shown in table 2 indicates that education is a major factor influencing the allocative (cost) efficiency of maize farmers in the study area. The coefficient of education is estimated to be negative, implying that as farmer acquire more formal education, the better their allocative efficiency in production. Also, the coefficient of household size is statistically significant at $1 \%$ level and it had a negative sign which implies that the inefficiency among maize farmers in the study area reduces with an increase in number of adult in the household who participated in farming activities. This is in consonance with the findings of Tashikalma et al. (2014) who reported that greater family size of average working age increases efficiency because most farmers are financially constrained.

The coefficient of gender is positive and statistically significant at $1 \%$ level, and thus disagreeing with the apriori expectation. This implies that gender difference in the study area does not influence the inefficiency among the farmers. The possible reason for this might be that female gender among the farmers are educated and can as well do better in maize production as the male. 
Table 2: Maximum Likelihood Estimates of the Parameters of the Stochastic Frontier Cost Function

\begin{tabular}{lllll}
\hline Variable & Parameter & Coefficient & Standard Error & t-ratio \\
\hline Cost Factors & & & & \\
Constant & $\beta_{0}$ & 1.4990 & 0.1646 & $9.1057^{* * *}$ \\
Cost of Land $\left(\mathrm{P}_{1}\right)$ & $\beta_{1}$ & 0.7283 & 0.0443 & $16.4578^{* * *}$ \\
Cost of Seed $\left(\mathrm{P}_{2}\right)$ & $\beta_{2}$ & 0.1586 & 0.0580 & $2.7321^{* * *}$ \\
Cost of Fertilizer $\left(\mathrm{P}_{3}\right)$ & $\beta_{3}$ & 0.0323 & 0.0358 & 0.9026 \\
Cost of Family labour $\left(\mathrm{P}_{4}\right)$ & $\beta_{4}$ & 0.0763 & 0.4344 & 0.1756 \\
Cost of Hired labour $\left(\mathrm{P}_{5}\right)$ & $\beta_{5}$ & 0.0113 & 0.0046 & $2.46762^{* *}$ \\
Cost of Agrochemical $\left(\mathrm{P}_{6}\right)$ & $\beta_{6}$ & 0.1410 & 0.0630 & $2.2373^{* *}$ \\
Inefficiency effects & & & & -1.3488 \\
Age of the Farmers $\left(\mathrm{Z}_{1}\right)$ & $\delta_{1}$ & -2.7080 & 2.0077 & $-2.3589^{* *}$ \\
Farming Experience $\left(\mathrm{Z}_{2}\right)$ & $\delta_{2}$ & -0.1513 & 0.0642 & $-3.3671^{* * *}$ \\
Education $\left(\mathrm{Z}_{3}\right)$ & $\delta_{3}$ & -0.2745 & 0.0815 & $-2.8935^{* * *}$ \\
Household Size $\left(\mathrm{Z}_{4}\right)$ & $\delta_{4}$ & -0.1375 & 0.0475 & -0.0327 \\
Extension Contact $\left(Z_{5}\right)$ & $\delta_{5}$ & -0.0014 & 0.0440 & $-3.2794^{* * *}$ \\
Gender $\left(Z_{6}\right)$ & $\delta_{6}$ & 0.1278 & 0.0390 & -0.6835 \\
Cooperative Membership $\left(Z_{7}\right)$ & $\delta_{7}$ & -0.0360 & 0.0527 & \\
Diagnostic Statistics & & & & $1.8778^{* * *}$ \\
Sigma squared $\left(\sigma^{2}\right)$ & & 0.1283 & 0.0683 & $39.3813^{* * *}$ \\
Gamma $(\gamma)$ & & 0.8286 & 0.0210 & \\
Log likelihood function & 116.8329 & & \\
\hline
\end{tabular}

Source: Computer output from Frontier 4.1 version.

${ }^{\star}$ Significant at $10 \%$ level, ${ }^{* *}$ Significant at $5 \%$ level, and ${ }^{* * *}$ Significant at $1 \%$ level.

The distribution of farmers' allocative efficiency indices derived from the analysis of the stochastic cost function were presented in the table 3 . The allocative efficiency of the sampled farmers ranged from 0.44 to 0.98 . The mean allocative efficiency was estimated as 0.68 , meaning that an average farmer in the study area has the ability of increasing allocative efficiency by $32 \%$ in the short-run under the existing technology. The average farmer allocative efficient $(A E=0.68)$ has the scope of increasing allocative efficiency by $30 \%$ to attain the level of the best allocatively efficient farmer in the study area; and also has the scope of increasing allocative efficiency by $32 \%$ to attain allocative efficiency frontier. This result shows that farmers in the study area were relatively allocative efficient in producing a given level of output using cost minimizing input ratios.

Table 3: Distribution of Efficiency indices of the Maize Crop Farmers

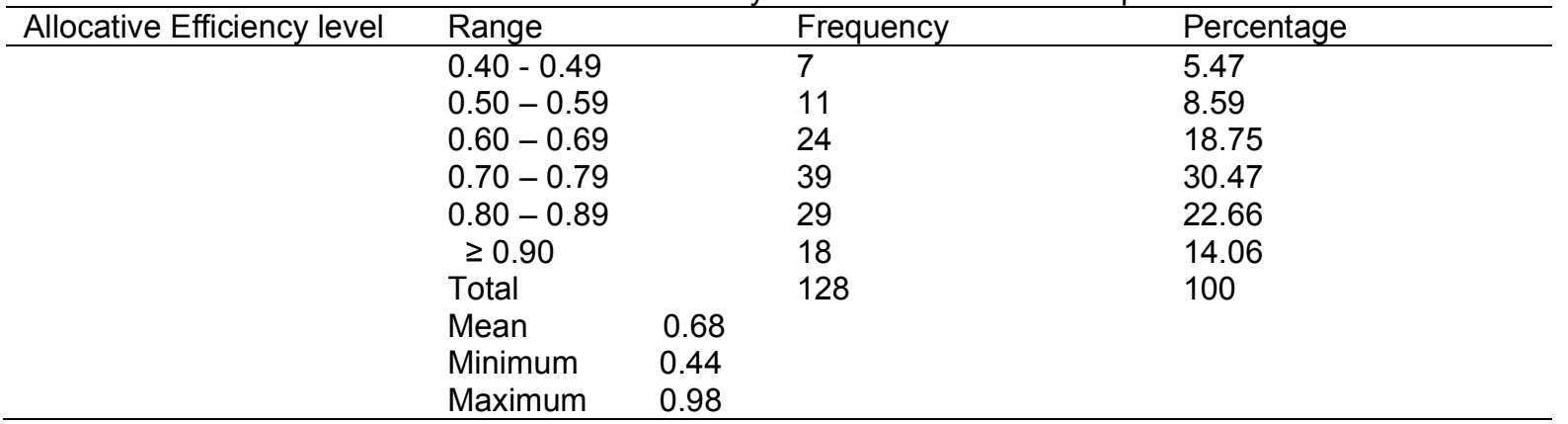

Source: Field survey, 2014

\section{CONCLUSION AND RECOMMENDATION}

In conclusion, the study found a significant relationship exists between the allocative efficiency and cost of land, cost of seed, cost of hired labour and cost of agrochemicals. In addition the analysis of cost efficiency index ranged from 0.44 to 0.98 with mean allocative efficiency of 0.68 , an indication that allocative efficiency of farmer can be increased by $32 \%$ in the short-run given the existing technology. The inefficiency model revealed that farming experience, education and household size are the socio-economic variables that had significantly reduce cost inefficiency among the farmers.

It is therefore recommended that policy measure such as increasing access of farmers to quality education, provision of adequate training progammes to farmers to enhance efficiency in their job performance, provision of adequate farm inputs at the right time; as well as deliberate policy of allocating farm land for farming activities. All these will enhance their cost efficiency and will have a corresponding effect on cost reduction and effective combination of input resources. 


\section{REFERENCES}

Adamawa State Government Diary, 2013.

Adamawa State Primary Health Care Development Agency., 2014. 7-8.

Ajibefun, I. A and Daramola, A. G., 2003. Efficiency of Micro-Enterprises in the Nigeria Economy. African Economic Research Consortium (AERC) Nairobi, Kenya.

Ali, M., 1996. Quantifying the Socio-Economic Determinants of Sustainable Crop Production: An Application to Wheat Cultivation in the Tarui of Nepal. Journal of Agricultural Economics.14:45-60.

Giroh, D. Y., 2012. Efficiency of Latex Production and Labour Productivity in Rubber Plantation in Edo and Delta State, Nigeria. Unpublished Doctoral Thesis, Modibbo Adama University of Technology, Yola, Adamawa State.

Iken, J. E and Amusa, N. A., 2004. Maize Research and Production in Nigeria. African Journal of Biotechnology, 3(6): 302-307.

Kareem, R. O., Aromolaran, A. B and Dipeolu, A. O., 2009. Economic efficiency of fish farming in Ogun State, Nigeria. Aquaculture Economics \& Management, 13:1, 39- 52.

Maurice, D. C., Adamu, Y and Joseph, M., 2015. Analysis of Cost Efficiency in Food Crop Production among Small-scale Farmers in Adamawa State, Nigeria. Global Journal of Agricultural Sciences. 14: 17-25.

Obidi, 2009. Economic Efficiency of Maize Production in Yola North and South Local Government Area, Adamawa State, Nigeria. $2^{\text {nd }}$ Seminar paper presented to the Department of Agricultural Economics and Extension, Federal University of Technology, Yola, Nigeria. Pp 11-12.

Ogundari, K. and Ojo S.O., 2007. Economic Efficiency of Small Scale Food Crop Production in Nigeria: A Stochastic Frontier Approach. Journal of Social Science, 14 (2): 123-130.
Ogundele, O. O., 2003. Technology Differentials and Resource-Use Efficiency of Production in Kaduna State, Nigeria. Unpublished Doctoral Thesis, University of Ibadan

Olayide, S. O and Heady, E. O., 1982. Introduction to Agricultural Production Economics. University press, University of Ibadan, Nigeria.

Onuk, E. G., Ogara, I. M., Yahaya, H and Nannim, N., 2010. Economic Analysis of Maize Production in Mangu Local Government Area of Plateau State, Nigeria. Production Agricultural Technology Journal, 6(1): 1-11.

Paudel, P and Matsuka, A., 2009. Cost Efficiency Estimates of Maize Production in Nepal: A Case study of the Chitwan District. Journal of Agricultural Economics-CZECH. 55,(3):139-148.

Tashikalma, A. K., Sani, R. M and Giroh, D. Y., 2014. Comparative Profitability of Selected Rainfed and Irrigated Food Crops in Adamawa State, Nigeria. Global Journal of Pure and Applied Sciences 20:77-87.

Uche, I. H., 2012. Food Insecurity in Nigeria. http:www.vanguardngr.com/2012/02/for-howlong-long-will-nigeria-continue-with-this-importsyndrom-madness/\#sthash.fQYKewgr.dpuf. Accessed on 19/2/2013.

Udoh, E. J., 2005. Technical Inefficiency in Vegetable Farms of Humid Region: An Analysis of Dry Season Farming by Urban Women in SouthSouth Zone, Nigeria. Journal of Agricultural science 1: 80-85.

Umoh, G. S., 2006. Resource Use Efficiency in Urban Farming: An application of Statistics Frontier Production Function. International Journal for Agricultural Biology, 8(1): 3844 .

Zalkuwi, J., Maurice, D. C and Yusuf, C., 2014. Determinant of Cost Efficiency in Cowpea Production: A Case Study of Adamawa State, Nigeria. International Journal of Science and Research, 3, (9): 407-410. 


\section{APPENDIX 1}

Table 1: Selection of Respondents

\begin{tabular}{llcc}
\hline $\begin{array}{l}\text { Local Government } \\
\text { Area }\end{array}$ & Ward sampled & $\begin{array}{c}\text { Population } \\
\text { of Farmers }\end{array}$ & No. of Selected Respondents \\
\hline Yola North & Doubeli & 26 & 14 \\
& Gwadabawa & 26 & 14 \\
& Jambutu & 32 & 17 \\
& Karewa & 30 & 16 \\
& Rumnde & 26 & 14 \\
Yola South & Sub-Total (i) & 140 & 75 \\
& Bole/Yolde Pate & 28 & 15 \\
& Makama A & 26 & 14 \\
& Mbamba & 25 & 13 \\
& Namtari & 38 & 20 \\
& Ngurore & 43 & 23 \\
& Sub-Total (ii) & 160 & 85 \\
& Total & $\mathbf{3 0 0}$ & $\mathbf{1 6 0}$ \\
\hline
\end{tabular}

Source: Field survey, 2014 